\title{
Internal and External Relative Clauses in Ancient Greek
}

\author{
Stefanie Fauconnier* \\ University of Leuven \\ stefaniefauconnier@gmail.com
}

\begin{abstract}
In this paper I argue that Ancient Greek has two distinct strategies for relative clause formation, corresponding to what is known in typology as externally and internally headed relative clauses. Furthermore, I explore two differences between these constructions. First, in comparison with their external counterparts, internal constructions are more restricted semantically. They can only be interpreted as restrictive relative clauses, while external constructions can also be interpreted as non-restrictive. Second, internal constructions are more restricted syntactically, given that they are not used when the domain nominal is subject in the relative clause. For external constructions there is no such syntactic restriction. Finally, I point out a number of convergences between internal relative clauses and noun phrases with an attributive participle. The findings presented in this paper are based on a study of Xenophon.
\end{abstract}

\section{Keywords}

Ancient Greek - internal relative clauses - external relative clauses - attributive participles

* An earlier version of this paper was presented at the conference 'Historical-Comparative Linguistics in the 21st Century', hosted by Silvia Luraghi in Pavia in September 2011. I would like to thank Silvia Luraghi for giving me the opportunity to present my work, and the members of the audience for their interesting questions and remarks. Furthermore, I would like to thank Jean-Christophe Verstraete and two anonymous reviewers for their careful reading and detailed comments. Of course, responsibility for any remaining inaccuracies or mistakes is entirely my own. This research was funded by the project "Optional ergative marking and the architecture of case systems" (от/08/o11, Research Council of the University of Leuven). 
This paper discusses two types of relative clauses in Ancient Greek. These two types are illustrated in examples (1a) and (1b).

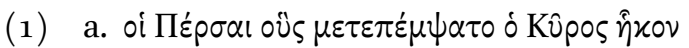

hoi Pérsai hoùs metepémpsato

DEF.NOM.M.PL Persian.NOM.M.PL REL.ACC.M.PL summon.AOR.3SG

ho Kûros hêkon

DEF.NOM Cyrus.NOM have.come.3PL

'The Persians whom Cyrus had summoned had come'

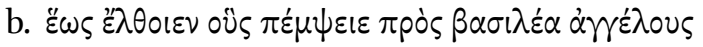

héōs élthoien hoùs pémpseie pròs

until come.AOR.OPT.3PL REL.ACC.M.PL send.AOR.OPT.3SG to

basiléa angélous

king.ACC messenger.ACC.M.PL

'Until the messengers whom he would send to the king would have come'

Xenophon, Cyropaedia 5.5·3; Agesilaus 1.10

Both examples contain a noun that is modified by a relative clause, marked with a relative pronoun. In example (1a), this is Pérsai ('Persians'), and in example ( $1 \mathrm{~b})$ this is angélous ('messengers'). These nouns are sometimes labeled as 'antecedents', but in this paper I refer to them as 'domain nominals' (see Andrews 2007). When comparing the constructions found in these examples, one can note a number of similarities, but also striking differences.

In the clause in example (1a), the relative clause follows the domain nominal Pérsai and is introduced by the relative pronoun hoùs. This relative pronoun agrees with the domain nominal in number (plural) and gender (masculine), but not in case marking. The case marking of the domain nominal depends on the function it fulfills in the main clause. Given that 'Persians' is the subject of the verb 'come', it is nominative-marked. The case marking of the relative pronoun, by contrast, is determined by the function the domain nominal fulfills in the relative clause. It serves as the direct object of the verb 'summon', so the relative pronoun hoùs is accusative-marked.

The construction found in example ( $1 \mathrm{~b})$ is similar to the one in (1a) in that there is a domain nominal angélous ('messengers') that is modified by a relative clause introduced by the relative pronoun hoùs. Again, this pronoun agrees with the domain nominal in number (plural) and gender (masculine). Furthermore, just like in (1a), the pronoun's case marking is determined by the 
function of the domain nominal within the relative clause. 'Messengers' serves as the direct object of the verb 'send', so the relative pronoun is accusativemarked. There are also a number of important differences with (1a), however. In (1b), the domain nominal does not precede the relative clause, but is included in it. Next, its case marking is not determined by the function it fulfills in the main clause: 'messengers' interpreted as the subject of the verb 'come', but it is not nominative-marked. Instead, the case marking depends on its function within the relative clause: 'messengers' is accusative-marked because it is the direct object of the verb 'send'. As a result, the relative pronoun hoùs and the domain nominal angélous do not only agree with each other in number (plural) and gender (masculine), but also in case marking (accusative).

In the existing literature on Ancient Greek, constructions such as those in (1b) are generally treated as a special type of the construction in (1a), where the domain nominal has moved into the relative clause. The terminology that is used to describe this phenomenon is rather diverse. Kühner \& Gerth (1963 [1904]) label it as Umstellung (transposition), Schwyzer \& Debrunner (1953) opt for the term Verschränkung (entanglement), Smyth \& Messing (1956) talk about incorporation, Rijksbaron (1981) uses the term displacement and Cooper \& Krüger (1998) say that the domain nominal is "taken up into the relative clause". In this paper, I argue that the constructions in $(1 \mathrm{a})$ and $(\mathrm{lb})$ correspond to what has been described in the typological literature as "external" and "internal" relative clauses (see e.g. Keenan \& Comrie 1977, Keenan 1985, Andrews 2007, Dryer 2011, Lehmann 1984). The reasons for this are discussed in section 2. In anticipation of the analysis, I label constructions such as found in (1a) as 'external relative clauses', and constructions such as found in ( $(\mathrm{b})$ as 'internal relative clauses'.

Furthermore, I also argue that external and internal relative clauses are not equivalent to each other (section 3). Internal relative clauses have a narrower scope than their external counterparts with respect to two different aspects. First, internal relative clauses can semantically only be interpreted as restrictive relative clauses, whereas external ones can also be interpreted as non-restrictive. Second, I show that internal relative clauses are restricted with respect to the syntactic contexts they occur in. Generally, they cannot be used when the domain noun functions as the subject of the restrictive relative clause.

The analysis presented in this paper is based on a study of the relative pronoun hós in Xenophon's historical-biographical works (Hellenica, Anabasis, Cyropaedia and Agesilaus), which date back to the 4th century ВСЕ. These works are written in a variant of Ancient Greek that is mainly Attic, but also 
contains a number of Doric and Ionic elements (see e.g. Gautier 1911, Luraghi 2003). ${ }^{1}$

\section{Relative Clauses in Ancient Greek: Internal vs External}

In this section I explain why I analyze constructions such as (1a) and (1b) as external and internal relative clauses, respectively. In linguistic typology, the terms "external" and "internal" are used to refer to two different strategies for relative clause formation (see e.g. Keenan \& Comrie 1977, Keenan 1985, Andrews 2007). As shown by Dryer (2011), both strategies are well-attested cross-linguistically. In external constructions, the domain noun stands outside the modifying relative clause. In internal constructions, by contrast, the domain nominal is syntactically part of the modifying relative clause. Both possibilities are illustrated by examples $(2 \mathrm{a})$ and $(2 \mathrm{~b}){ }^{2}$

(2) a. ketab-i [ke be mæn dad-id] gomšode æst book-INDF [REL to 1SG.ACC give.PST-2SG] lost be.3SG 'The book you gave to me is lost' external relative clause PERSIAN (Andrews 2007: 209)

b. wiłqa?-ni [ni? $\mathrm{k}=\mathrm{u} \quad$ wu-kat pałkiy] big-IND [DEF SUB-1SBJ see woman] 'The woman that I saw was tall' internal relative clause KutenAI (Dryer 2007: 202)

I argue that Ancient Greek exhibits both types of strategies: constructions such as (1a) correspond to external relative clauses, whereas the construction found in ( $1 \mathrm{~b}$ ) corresponds to an internal relative clause. The external construction is discussed in 2.1, and the internal construction is discussed in 2.2.

\subsection{The External Construction}

In this section I discuss constructions such as found in (1a). A similar example is found in (3). I argue that this type of construction can be analyzed as an

1 The reason I chose Xenophon for this paper is that his works are written in an uncomplicated, relatively unadorned Attic Greek. Compared to poetic or highly rhetorical works, his writings are free from convoluted, exotic constructions, which makes linguistic analysis much more simple.

2 These examples are from two different languages, but there are also languages where both type of constructions coexist (Dryer 2011). Ancient Greek is not unique in this regard. 
external relative clause for two reasons. The first is related to the case marking of the domain nominal, whereas the second is related to its position with respect to the restrictive relative clause.

(3) $\tau \hat{\omega} \alpha \dot{\alpha} \nu \delta \rho i o ̄ \nu ~ \alpha े \nu ~ घ ं \lambda \eta \sigma \theta \varepsilon \pi \varepsilon i \sigma o \mu \alpha l$

tồi andrì hòn àn hélēsthe peísomai

DEF.DAT man.DAT REL.ACC PRT choose.SBJV.2PL obey.1SG

'I will obey the man you will choose'

Xenophon, Anabasis 1.3.15

First, the domain nominal in clauses such as those in (1a) and (3) can be argued to stand outside the following relative clause because of its case marking. This is determined by its function in the main clause, and not by its function in the subordinate clause. Above I explained that this is the case in (1a), and a similar analysis obtains for example (3). The domain nominal andri ('man') is dative-marked because it is the object of the verb of the main clause ('obey'), which governs the dative. If its case marking depended on its function within the relative clause, it would be accusative-marked, as the direct object of the verb 'choose'. Another example that illustrates this is (4).

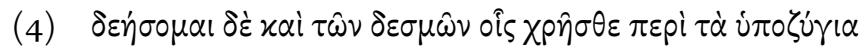
deếsomai dè kaì tồn desmồn hoîs need.FUT.1SG PRT and DEF.GEN.PL strap.GEN.PL REL.DAT.PL chrêsthe perì tà hypozýgia use.PRS.2PL for DEF.ACC.PL pack.animal.ACC.PL 'I will also need the straps you use for the pack animals' Xenophon, Anabasis 3.5.10

In this example, the domain nominal desmôn ('straps') is followed by a relative clause introduced by hoîs. The case marking of this noun does not depend on its function within the relative clause, where it serves as a dative object of the verb 'use', but on its function in the main clause. As the complement of the verb 'need', it is genitive-marked.

Second, the position of the domain nominal also indicates that it is syntactically not part of the relative clause itself. In examples (1a), (3) and (4), the domain nominal precedes the relative clause, and is not included in it. Furthermore, the relative clause does not always directly follow the domain nominal. This is illustrated in example (5). 


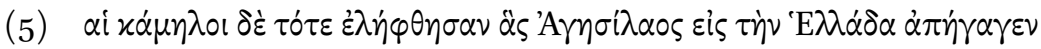

hai kámēloi dè tóte elêphthēsan hàs

DEF.NOM.PL camel.NOM.PL PRT then take.PASS.AOR.3PL REL.ACC.PL

Agēsílaos eis tè̀n Helláda apégagen

Agesilaus.NOM to DEF.ACC Greece.ACC bring.back.AOR.3SG

'The camels that Agesilaus brought back to Greece were captured at that point'

Xenophon, Hellenica 3.4.24

Here, the domain nominal kámeeloi ('camels') is separated from the relative clause by the verb from the main clause, as well as by a temporal adverb. This also indicates that the domain nominal is not part of the relative clause.

\section{$2.2 \quad$ The Internal Construction}

On the other hand, constructions such as found in (1b) can be analyzed as internal relative clauses. A similar example is found in (6). There are four elements which indicate that the domain nominal is syntactically part of the relative clause, and does not stand outside it. The first element relates to case marking, the second one to the position of the domain nominal, the third one to the use of anaphoric pronouns, and the fourth one to the lack of the definite article.



toùs bouloménous hypakoûsai hè̀n basileùs

DEF.ACC.PL want.PRS.PTCP.ACC.PL obey.AOR.INF REL.ACC king.NOM eirénēn katapémpoi

peace.ACC send.PRS.OPT.3SG

'Those who wanted to obey the peace treaty that the king had sent'

Xenophon, Hellenica 5.1.30

First, as was noted above, the use of case marking in example ( $1 \mathrm{~b})$ indicates that the domain nominal is integrated in the relative clause. This is also the case in example (6), where the domain nominal is eirếnén ('peace'). This domain nominal is accusative-marked because it is the direct object of the verb in the relative clause (katapémpoi, 'send'). If its case marking were determined by its function in the main clause, it would be genitive-marked as the complement of the verb hypakoûsai, which governs the genitive. This implies that the domain nominal is a dependent of the verb of the relative clause. As a result, the domain nominal is syntactically part of the relative clause. Another illustration of this is found in example (7), where the case marking of the domain 
nominal also depends on its function within the relative, and not the main clause.

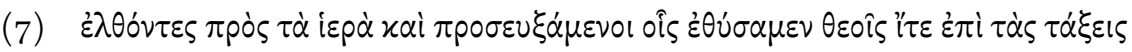
elthóntes pròs tà hierà kaí go.AOR.PTCP.NOM.PL to DEF.ACC.PL temple.ACC.PL and proseuxámenoi hoîs ethýsamen theoîs worship.AOR.PTCP.NOM.PL REL.DAT.PL sacrifice.AOR.PL god.DAT.PL íte epì tàs táxeis go.IMP.PL to DEF.ACC.PL rank.ACC.PL 'After having gone to the temples and having worshipped the gods to whom we have sacrificed, go to your ranks'

Xenophon, Cyropaedia 6.4.19

In this example, the domain nominal theois ('gods') is dative-marked because it is the indirect object of the relative clause. If its case marking were determined by its function in the main clause, it would be accusative-marked as the direct object of proseuxámenoi.

Second, constructions such as found in (6) can be argued to be internal relative clauses because of the position of the domain nominal. In this example, the domain nominal does not precede the relative clause, but is included in it. As a result, the nominal can only be analyzed as part of the relative clause. This is also the case for the domain nominal nikēn ('victory') in example (8). Note that the domain nominal does not immediately follow the relative pronoun. This behavior appears to be structural; I could not find any counterexamples.

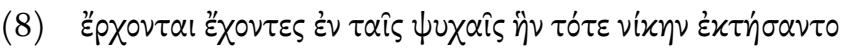

érchontai échontes en taîs psychaîs hè̀n
go.PRS.3PL have.PTCP.NOM.PL in DEF.DAT.PL SOUl.DAT.PL REL.ACC tóte níkēn ektếsanto then victory.ACC acquire.AOR.3PL

'They go, having in their minds the victory they achieved at that time' Xenophon, Cyropaedia 6.2.15

In a number of internal relative clauses, the position of the domain nominal does not unambiguously indicate that it is part of the relative clause. This is illustrated in (9), where the domain nominal Pérsas ('Persians') is at the edge of the relative clause (see also examples (1b) and (7) above). 


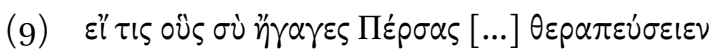

eí tis hoùs sù ègages Pérsas

if INDF.NOM REL.ACC 2SG.NOM bring.AOR.2SG Persian.PL.ACC therapeúseien

flatter.AOR.OPT.3SG

'If somebody would flatter the Persians whom you brought here'

Xenophon, Cyropaedia 5.5.31

In cases like this, it could be argued that the domain nominal is integrated in the relative clause, but it could in principle also be argued that the domain nominal follows the relative clause while not being part of it. Furthermore, in example (9) the use of case marking does not help us to decide whether this is an internal or an external relative clause, either. The domain nominal functions as the direct object of both the main clause and the relative clause, so it is not possible to say on which one the case marking of the domain nominal is based. Still, it is possible to argue that relative clauses like this one ${ }^{3}$ are internal, by looking at parallel constructions where the domain nominal does have different functions in the main clause and the relative clause. In the texts that were consulted for this study, such constructions always show a domain nominal whose case marking depends on the relative clause. This is illustrated in examples ( $1 \mathrm{~b}),(7)$ and also in (10).

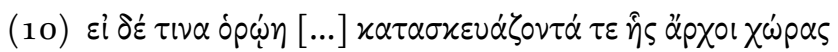

ei dé tina horốiē kataskeuázontá te hềs

if PRT INDF.ACC see.PRS.OPT.3SG cultivate.PTCP.ACC PRT REL.GEN árchoi chốras rule.PRS.OPT.3SG country.GEN

'If he would see somebody who cultivated the land over which he ruled'

Xenophon, Anabasis 1.9.19

Here, the domain nominal chốras ('land') is at the edge of the relative clause. It functions as a direct object within the main clause, but as a genitive complement in the relative clause (árchoi, 'rule', governs the genitive). Inasmuch as the domain nominal has genitive, and not accusative case marking, it is clear that it is construed as a dependent of the verb from the relative clause.

The third point of evidence that shows that the construction discussed here exemplifies an internal relative clause is related to the use of anaphoric

3 It should be noted that this is not an isolated or rare case, see for instance also example (13). 
pronouns. In a number of examples, the domain nominal from the internal relative clause is "taken up" in the main clause by a resumptive anaphoric pronoun. This is the case in example (11).

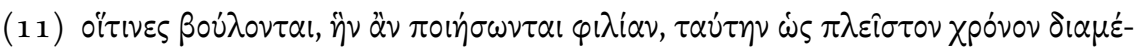
veเv

hoítines boúlontai, hè̀n àn poiếsōntai

INDF.NOM.PL want.PRS.3PL REL.ACC PRT make.SBJV.3PL

philían, taútēn hōs pleîston chrónon diaménein friendship.ACC DEM.ACC as most.ACC time.ACC last.PRS.INF 'Whoever men wish that the friendship which they establish may last for the longest possible time' (the friendship they establish, that it may last ...)

Xenophon, Hellenica 6.3.7

In this example, the main clause contains the anaphoric pronoun taútēn, referring to philian ('friendship'), the domain nominal from the internal relative clause. If this domain nominal were part of the main clause, it would not be necessary to use an anaphor here. ${ }^{4}$

The fourth piece of evidence relates to the lack of the definite article. In clauses exhibiting the construction discussed here, the domain nominal is always formally indefinite, i.e. it is never preceded by the definite article. According to Basilico (1996), this is a typical cross-linguistic characteristic of internal relative clauses. Compare for instance examples (12a) and (12b).

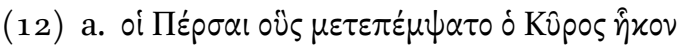
hoi
Pérsai
hoùs
metepémpsato

DEF.NOM.PL Persian.NOM.PL REL.ACC.PL send.for.AOR.3PL

ho Kûros hềkon

DEF.NOM Cyrus.NOM have.come.3PL

'The Persians whom Cyrus had sent for had come'

4 Note that the anaphoric pronoun cannot be interpreted as a demonstrative pronoun that directly modifies philían. In that case it would precede rather than follow the noun. 


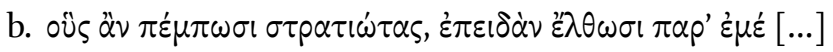

hoùs àn pémpōsi stratiótas, epeidàn
REL.ACC.PL PRT send.SBJV.3PL soldier.ACC.PL when
élthōsi par' emé
come.SBJV.3PL to 1SG.ACC
'The soldiers they sent, after they have come to me ...'
Xenophon Cyropaedia $5 \cdot 5 \cdot 3,4.5 .17$

The clause in (12a) contains an external relative clause, where the domain nominal is preceded by the definite article hoi. The clause in (12b), by contrast, contains an internal relative clause where the domain nominal, even though semantically definite, is not preceded by the article. This absence is not surprising given that the domain nominal belongs to a syntactic unit that is already definite, and that it is introduced by the relative pronoun. Another example that illustrates this property of internal relative clauses is (13). Here, the domain nominal is again semantically definite, while this is not marked by the use of the definite article (as is also the case in the other examples discussed above).

(13) ol ỏp hoi oreokómoi dè aporriptoûntes DEF.NOM.PL mule-driver.NOM.PL PRT throw.away.PRT.NOM.PL hòn eilếphesan karpòn apếlaunon oíkade REL.ACC take.PQP.3PL fruit.ACC drive.away.IPFV.3PL homewards 'The mule-drivers, throwing away the fruit they had seized, drove away homewards'.

Xenophon Hellenica 5.4.42

In this section, I have shown that Ancient Greek has two syntactically different relative clause constructions, one that corresponds to an external relative clause and one that exemplifies an internal relative clause. Their formal characteristics are summed up in table 1. In the next section, I compare the distribution of the internal construction with the distribution of the external construction.

\section{Differences between Internal and External Relative Clauses}

In this section I argue that, in the texts examined here, the use of the internal and external relative constructions is not just a matter of free variation. The 
TABLE 1 Behavior of the domain nominal in external and internal relative clauses

\begin{tabular}{lll}
\hline & External & Internal \\
\hline Case & main clause & rel. clause \\
Position & outside rel. clause & inside rel. clause \\
Article when definite & yes & no \\
\hline
\end{tabular}

internal construction is narrower in scope than the external construction in two respects, one semantic (discussed in section 3.1) and one syntactic (discussed in section 3.2).

\subsection{Semantic Difference}

Semantically, internal relative clauses can only function as 'restrictive' relative clauses, whereas external relative clauses can function as both 'restrictive' and 'non-restrictive'. I use the terms restrictive and non-restrictive in the sense of Jespersen (1924) (see also Quirk 1957, Keenan 1985). A restrictive relative clause delimits, or "narrows down" the domain of reference of the domain nominal, whereas a non-restrictive relative clause merely adds a "loose" comment about it (for a more detailed description, see Fabb (1990)). The difference between restrictive and non-restrictive relative clauses is illustrated in examples (14a) and (14b). In both cases the external construction is used.


xai $\tau \dot{\eta} \nu \tau \hat{\omega} \nu \Sigma \kappa \nu \theta \eta \nu \omega \hat{\nu}$

tềi prốtēi de hēmérai aphíkonto epì tòn DEF.DAT first.DAT PRT day.DAT arrive.AOR.3PL at DEF.ACC potamòn hòs ốrize tèn tôn river.ACC REL.NOM separate.IPFV.3SG DEF.ACC DEF.GEN.PL Makrónōn kaì tến tôn Skythēnồn Macronian.GEN.PL and DEF.ACC DEF.GEN.PL Scythinian.GEN.PL 'On the first day they arrived at the river that separated the [territory] of the Macronians from the [territory] of the Scythinians.' 


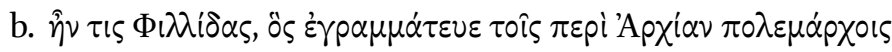

ên tis Phillídas, hòs

be.IPFV.3SG INDF.NOM Phillidas.NOM REL.NOM

egrammáteue toîs perì Archían

be.secretary.IPFV.3SG DEF.DAT.PL around Archias.ACC

polemárchois

officer.DAT.PL

'There was a certain Phillidas, who acted as a secretary for the officers surrounding Archias'

Xenophon Anabasis 4.8.1; Hellenica 5.4.2

The relative clause in (14a) is restrictive because it delimits the domain of reference of the domain nominal 'river'. The relative clause serves to identify the river that is being referred to. The relative clause in (14b), by contrast, is non-restrictive because it merely adds a comment about the domain nominal 'Phillidas'. It does not indicate which specific instance of Phillidas is being referred to, but just provides some additional information.

Whereas external relative clauses can be both restrictive and non-restrictive, as illustrated in (14), internal relative clauses are always restrictive. This is the case for the examples cited above, and also for (15).

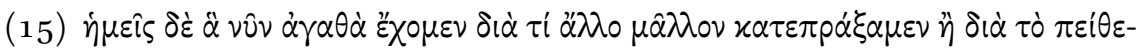



hēmeîs dè hà nŷn agathà échomen dià 1PL.NOM PRT REL.ACC.PL now good.ACC.PL have.3SG through tí állo mâllon katepráxamen è dià INTERROG.ACC other.ACC more achieve.AOR.1PL than through tò peíthesthai tồi árchonti;

DEF.ACC obey.PRS.INF DEF.DAT ruler.DAT

'The good things that we now have, through what other means have we achieved them more than by obeying the commander?'

Xenophon Cyropaedia 8.1.3

The domain nominal in this example is agathà, 'good things'. This domain nominal is delimited by the restrictive clause, which specifies which good things are being referred to. Without the relative clause, the reference of agathà could not be identified.

Given that restrictive relative clauses delimit the domain nominal, they are not expected to occur with proper names very often. Proper names have a unique referent, and as a result they do not need to be delimited in order to 
be identified. Because of this, restrictive relative clauses are used only rarely with proper names in English, for instance in cases where only one aspect of the referent is profiled (see e.g. De Haan 1989). This is the case in the following examples from English.

(16) a. The Greece that got away from the Turks was a country of peasants, local clan chieftains and Orthodox priests, with only a sliver of a mercantile and professional upper class

b. They should look at the Europe that will exist in five or 1o years' time, at a Community with 18 or 20 members and perhaps even more, and at the interests that we have in common-security, defence, foreign policy, the environment, prosperity and peace in the world.

English (British National Corpus, Davies 2004-)

This implies that the internal construction, which is exclusively associated with restrictive relative clauses, is expected to occur only rarely with proper names. This prediction is borne out in the texts examined here: in only one instance does a proper name serve as the domain nominal. This instance is cited in example (17).

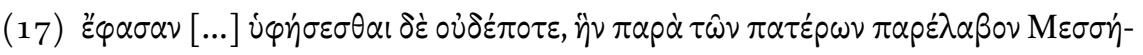
$\nu \eta \nu, \tau \alpha u ́ \tau \eta \varsigma \sigma \tau \varepsilon p \eta \theta \hat{\eta} \nu \alpha \mathrm{l}$

éphasan $[\ldots]$ hyphếsesthai dè oudépote hè̀n parà

say.AOR.3PL [...] submit.FUT.INF PRT never REL.ACC from

tồn patérōn parélabon Messếnēn, taútēs

DEF.GEN.PL father.GEN.PL receive.AOR.3PL Messene.ACC DEM.GEN sterēthênai

deprive.AOR.PASS.INF

'They said that the Messene that they had received from their fathers, that they would never submit to being deprived from that'.

Xenophon Hellenica 7.4.9

This difference between internal and external relative clauses can be seen as a form-function correspondence. In internal constructions, the domain nominal is part of the relative clause. This implies that the domain noun and the relative clause form one single syntactic unit that cannot be broken up. As a result of this tight syntactic integration, the relative clause can only be interpreted as directly modifying the domain nominal. External constructions, by contrast, can be analyzed as consisting of two units; the domain noun and the relative clause are not so tightly integrated as in internal constructions. As illus- 
trated in example (5), they can be separated from each other. Because of the looser syntactic connection, the relative clause can be interpreted as directly modifying the domain nominal, but it can also be interpreted as a loose comment.

\subsection{Syntactic Difference}

In this section I compare internal and external relative clauses in terms of the syntactic function that is fulfilled by the domain nominal. I will argue that internal constructions are not used when the domain nominal is the subject of the verb from the relative clause. For external constructions, by contrast, there is no such restriction. Furthermore, I will account for this difference in syntactic behavior by examining the relationship between internal relative clauses and participial constructions.

First, external constructions are used in all sorts of syntactic contexts. As illustrated in the examples below, the domain nominal's function within the relative clause can be subject, object, genitive complement, dative complement, etc.

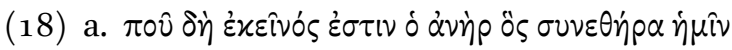

poû dē ekeînós estin ho anè̀r hos

where PRT DEM.NOM be.PRS.3SG DEF.NOM Man.NOM REL.NOM

synethếra hēmîn

hunt.together.IPFV.3SG 1P L.DAT

'Where is that man who used to hunt with us?'

Xenophon, Cyropaedia 3.1.38

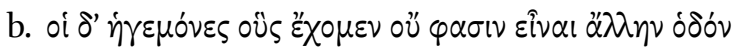

hoi d' hēgemónes hoùs échomen oú

DEF.NOM.PL PRT leader.NOM.PL REL.ACC.PL have.PRS.IPL NEG

phasin eînai állēn hodón

say.PRS.3PL be.PRS.INF other.ACC way.ACC

'The leaders we have, say there is no other way'

Xenophon, Anabasis 4.1.21

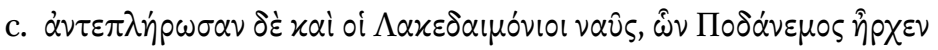

anteplếrōsan dè kaì hoi Lakedaimónioi

fill.AOR.3PL PRT and DEF.NOM.PL Lacedaemonian.NOM.PL

naûs hồn Podánemos ềrchen

ship.ACC.PL REL.GEN.PL Podanemos.nOM rule.IPFV.3SG

'And the Lacedaemonians filled ships, over which Podanemus had the command'

Xenophon, Hellenica 4.8.10 


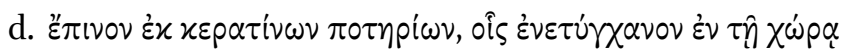
épinon ek keratínōn potēríon, hoîs drink.IPFV.3PL from made.of.horn.GEN.PL cup.GEN.PL REL.DAT.PL enetúnchanon en tềi chốrai stumble.upon.IPFV.3SG in DEF.DAT country.DAT 'They drank from cups made of horn which they found in the country' Xenophon, Anabasis 6.1.5

In (18a), the domain nominal 'man' functions as the subject of the verb of the relative clause ('hunt'). As a result, the relative pronoun is nominativemarked. (18b) illustrates how domain nominals in external constructions can also be the object of the verb of the relative clause. This is why the relative pronoun is accusative-marked. Next, in (18c) the domain nominal 'ships' is the genitive complement of the verb of the relative clause ('rule'), and the relative pronoun is genitive-marked. Finally, in (18d) the domain nominal is the dative complement of the verb 'find', and as a result the relative pronoun is dative-marked. Summing up, external relative clauses can be introduced by relative pronouns marked with the nominative, accusative, genitive or dative case, since the domain nominal can fulfill various syntactic functions within these relative clauses.

When we look at internal constructions, by contrast, a different picture emerges. In the texts consulted in this study, they are not used when the domain nominal fulfills the function of subject within the relative clause. Other functions are possible, however, as illustrated in the examples mentioned so far, and also in the ones below.

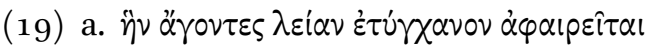

hè̀n ágontes leían etýnchanon
REL.ACC carry.PTCP.NOM.PL spoil.ACC happen.IPFV.3PL
aphaireîtai
rob.PRS.3SG

'He takes away the spoil which they happened to be carrying'

Xenophon, Cyropaedia 5.4.16 


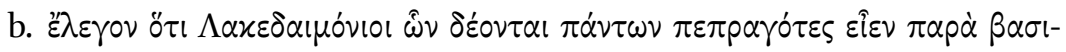
$\lambda \dot{\varepsilon} \omega \varsigma$

élegon hóti Lakedaimónioi hôn say.IPFV.3PL that Lacedaemonian.NOM.PL REL.GEN.PL

déontai pántōn pepragótes eîen parà need.PRS.3PL all.GEN.PL get.PRF.PTCP.NOM.PL be.PRS.OPT.3PL from basiléōs

king.GEN

'They said that the Lacedaemonians got everything they needed from the king'

Xenophon, Hellenica 1.4.2

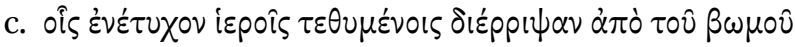

hoîs enétychon hieroîs

REL.DAT.PL stumble.upon.AOR.3PL offering.DAT.PL

tethyménois diérripsan apò toû

sacrifice.PRF.PTCP.DAT.PL throw.away.AOR.3PL from DEF.GEN

bōmoû

altar.GEN

'They threw the sacrificed offerings that they found from the altar'

Xenophon, Hellenica 3.4.4

In example (19a), the domain nominal 'spoil' is the direct object of the verb of the relative clause ('carry'). Hence, the domain nominal and the relative pronoun are accusative-marked. Next, within the relative clause from example (19b), the domain nominal 'everything' functions as the complement of the verb 'need', which governs the genitive. As a result, domain nominal and relative pronoun are genitive-marked. In example (19c), finally, the relative pronoun and the domain nominal 'offerings' are dative-marked because this domain nominal functions as a dative complement within the relative clause (the verb enétychon, 'stumble upon', governs the dative). Such internal constructions are never used when the domain nominal functions as the subject of the relative clause. As a result, the case marking of the domain nominal and the relative pronoun can be accusative, genitive or dative, but not nominative.

Such a restriction against 'nominative' internal relative clauses calls for an explanation. According to Keenan \& Comrie (1977), the subject function is cross-linguistically most easily accessible to relativization, so it is somewhat surprising that precisely this option is ruled out with internal constructions. The reasons for this can be better understood by comparing the relative clauses discussed here with another type of construction, where a noun is modified by 
a participle in attributive position. This type of construction is illustrated in example (20).

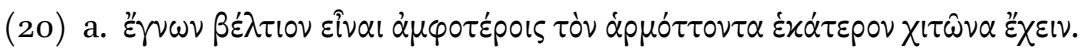
égnōn béltion eînai amphotérois tòn judge.AOR.ISG better be.PRS.INF both.DAT.PL DEF.ACC

harmóttonta hekáteron chitôna échein fit.PRS.PTCP.ACC each.ACC tunic.ACC have.PRS.INF 'I judged that it was better for them both to have the tunic that fitted each of them.'

Xenophon, Cyropaedia 1.3.17

b. îx hêkkon légontes hoi have.come.3PL say.PRS.PTCP.NOM.PL DEF.NOM.PL propemphthéntes skopoì hóti ouch send.ahead.PASS.AOR.PTCP.NOM.PL scout.NOM.PL that NEG hippeîs eisin horseman.NOM.PL be.PRS.3PL

"The scouts who had been sent ahead had come, saying that there were no horsemen'

Xenophon, Anabasis 2.2.15

In each of these examples, there is a noun phrase consisting of a noun and a definite article, with a participle in between (i.e. in the position associated with attributive adjectives). This participle specifies the instance of the noun that is being referred to. As a result, this noun phrase can be considered as functionally equivalent to a restrictive relative clause ('the fitting tunic' $\approx$ 'the tunic that fits', 'the sent scouts' $\approx$ 'the scouts who had been sent'), as also pointed out by Rijksbaron $(1981,2002)$. However, such a noun phrase only occurs when the noun functions as the subject of the modifying participle. In example (20a), 'tunic' is the subject of 'fit', and in ( $2 \mathrm{ob})$ 'scouts' is the subject of 'be sent'. It is not possible for a participle to modify a noun when there is no subject relation.

This implies that there are two different constructions that exclusively fulfill the function of restrictive relative clauses. First, there is the internal relative clause, which cannot be used when the domain nominal is the subject of the verb of the relative clause. Second, there is the noun phrase with a participle in attributive position, which can only be used in cases of subject relations. From this, it can be concluded that the two types of constructions are in complementary distribution. The internal construction is used in cases where 
the participle construction is not possible (see also Rijksbaron (2002: 92-93) for a similar suggestion). This may explain why internal constructions do not occur when the domain nominal is the subject of the verb from the relative clause: in those cases, the participle construction is used instead. ${ }^{5}$

Although the participle construction and the internal relative clause fulfill a similar function, it should be stressed that they are formally very different. In participle constructions, the domain nominal is the head of the syntactic unit, and it is modified by an article and a participle. As a result, the case marking of the participle agrees with that of the domain nominal. In turn, the domain nominal's case marking depends on its syntactic function in the main clause. In internal relative clauses, by contrast, the head of the syntactic unit is the subordinate verb, with the domain nominal as its dependent, given that its case marking depends on its relationship with this verb. This distinction between participle and internal constructions can be blurred in some cases, however. It appears that the close functional link between the two can give rise to the use of a hybrid construction type. Compare, for instance, the relative clause found in (21a) with the participle construction in (21b) and the regular internal relative clause in (21c).

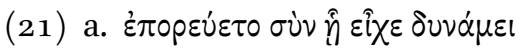

eporeúeto sùn hềi eîche dunámei

march.IPFV.3SG with REL.DAT have.IPFV.3SG force.DAT

'He set out with the force that he had'

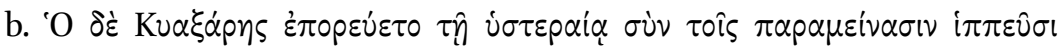
Mń $\delta \omega \nu$

ho dè Kyaxáres eporeúeto têi hysteraîai sỳn

DEF.NOM PRT Cyaxares march.IPFV.3SG DEF.DAT next.DAT with

toîs parameínasin hippeûsi Mềōn

DEF.DAT.PL stay.AOR.PTCP.DAT.PL horseman.DAT.PL Median.GEN.PL 'On the next day, Cyaxares set out with the Median horsemen who had stayed with him'

5 An anonymous reviewer suggested an alternative explanation for this observation. She or he points out that the domain nominal within restrictive relative clauses is typically indefinite (see for instance Cinque (2013:167)). On the other hand, the subject position is typically associated with definites. As internal relative clauses are inherently restrictive, this might explain why they are not used with subjects. While I find this explanation very interesting, I do not think it can be the full story. First, subjects are most often, but not exclusively definite in Ancient Greek. Second, I am not convinced that the domain nominal within a restrictive relative clause is necessarily indefinite in Ancient Greek. While this has been reported for a number of languages, I think more research is needed before this can be established as universal. 


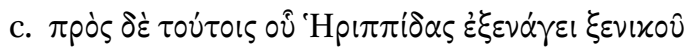
pròs dè toútois hoû Hērippídas
besides PRT DEM.DAT.PL REL.GEN Herippidas.NOM
exenágei xenikoû
command.IPFV.3SG mercenary.GEN
'Besides these, [there were] the mercenary troops over which Heripp- idas had command'

Xenophon Cyropaedia 5.5.5, Hellenica 4.1.23, 4.3.15

First, the relative clause in example (21a) shows a number of characteristics associated with internal constructions such as found in (21c). It is introduced by a relative pronoun, the domain nominal 'force' is within the relative clause and it has no definite article. However, this relative clause is also similar to participial constructions such as used in (21b) in that the verb appears to function as a dependent rather than a head. Not only is it in attributive position between the relative pronoun and the domain nominal, but, more importantly, it does not govern their case marking. Within the relative clause, the domain nominal 'force' is the direct object of the verb 'have', but neither this noun nor the relative pronoun are accusative-marked. Instead, they are dativemarked, in accordance with the domain nominal's function within the main clause (prepositional complement after syn, 'with'). This implies that the headdependent relationship found in internal constructions such as (21c) appears to be reversed here. Within the relative clause, the domain nominal is not the dependent of the verb, but rather the head, modified by a relative pronoun (agreeing with it in case marking) and a verb in attributive position. This is illustrated in figure 1. The resulting hybrid construction is not limited to this example, but recurs throughout Xenophon's work, and is especially common after propositions (such as in (21a)). ${ }^{6}$ It is further confirmation of the parallellism between internal relative clauses and NPs with an attributive participle.

The analysis proposed here is largely compatible with Rijksbaron's (1981, 2002) comments. In his 1981 paper, he argues that constructions such as (21a)

6 'Hybrid' internal relative clauses are not exclusively found after prepositions, however. The following examples illustrate both posibilities.

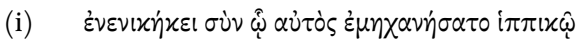
enenikếkei sỳn hồi autòs emēchanếsato hippikồi
defeat.PQP.3SG with REL.DAT self.NOM construct.AOR.3SG cavalry.DAT
'He had prevailed with the cavalary he had created himself' 


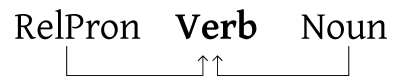

RelPron Verb Noun
FIGURE 1

Dependency structure in internal relative clauses (top) and in 'hybrid' constructions (bottom)

are analogous to participle constructions and have an "adjectival" finite verb. He does not analyze them as a hybrid between these constructions and regular internal relative clauses, however. In his 2002 book, he mentions both what I call regular and hybrid internal relative constructions, and analyzes both of them as functionally and structurally equivalent to constructions with an attributive participle.

Finally, my analysis of 'hybrid' internal relative clauses is not only compatible with existing work, but also with cross-linguistic knowledge. First, the change in the head-dependent relationship I argued for above is not unique. A similar phenomenon, known as 'dependency reversal', is attested in a number of languages from different families (see e.g. Malchukov 2000). Furthermore, a phenomenon where a relative clause structurally converges with noun phrases with an attributive modifier is also not unheard of. According to Andrews (2007: 232) such a phenomenon of 'nominalization' is commonly found with internal relative clauses.

\section{Conclusions}

In this paper, I have shown that Ancient Greek has two distinct types of relative clauses, one external and one internal. I have argued that the second construction type has a narrower scope than the first one, given that it is not used in non-restrictive contexts, or in cases where the domain nominal fulfills the function of subject within the relative clause. This last observation has been

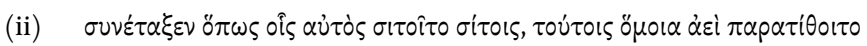
synétaxen hópōs hoîs autòs sitoîto sítois, order.AOR.3SG that REL.DAT.PL self.NOM eat.PRS.OPT.3SG food.DAT.PL toútois hómoia aè̀ paratíthoito DEM.DAT.PL similar.NOM.PL always serve.PRS.PASS.OPT.3

'He ordered that the food that he himself ate, that things similar to that had always to be served'

Xenophon, Agesilaus 2.5; Cyropaedia 8.2.3 
explained on the basis of the parallellism between internal relative clauses and noun phrases with an attributive participle.

Of course, the analysis proposed in this paper leaves much room for further research. First, the findings discussed here are based on a thorough examination of relative clauses in Xenophon, but a more extensive corpus study with an in-depth quantitative analysis was not attempted. Next, a broader corpus study that is not just based on Xenophon could further clarify the differences between internal and external relative clauses by taking, for instance, pragmatic factors into account. Another research topic that is not pursued in this paper is the historic development of both internal and external relative clauses. A diachronic study could offer more insights on how these constructions arose, and how they developed through the various stages leading up to present-day Modern Greek. Finally, it would also be interesting to compare Ancient Greek with other languages which have both internal and external relative clauses. Are the observations from this paper typologically very common, or rather exceptional?

\section{References}

Andrews, Avery D. 2007. Relative clauses. In Timothy Shopen (ed.), Language typology and syntactic description. Volume II: Complex constructions, 206-236. Cambridge: Cambridge University Press (2nd edn).

Basilico, David. 1996. Head position and internally headed relative clauses. Language $72(3) \cdot 498-532$.

Cinque, Guglielmo. 2013. Typological studies: Word order and relative clauses. New York: Routledge.

Cooper, Guy L. \& Karl Wilhelm Krüger. 1998. Attic Greek prose syntax. Ann Arbor: University of Michigan Press.

Davies, Mark. 2004-. BYU-BNC: The British national corpus. Available online at http:// corpus.byu.edu/bnc/.

De Haan, Pieter. 1989. Postmodifying clauses in the English noun phrase: A corpus-based study. Amsterdam: Rodopi.

Dryer, Matthew S. 2007. Noun phrase structure. In Timothy Shopen (ed.), Language typology and syntactic description. Volume II: Complex constructions, 151-205. Cambridge: Cambridge University Press (2nd edn).

Dryer, Matthew S. 2011. Order of relative clause and noun. In Matthew S. Dryer \& Martin Haspelmath (eds.), The world atlas of language structures online, Munich: Max Planck Digital Library. http://wals.info/chapter/9o.

Fabb, Nigel. 1990. The difference between English restrictive and non-restrictive relative clauses. Journal of Linguistics 26(1).57-77. 
Gautier, Léopold. 1911. La langue de Xénophon. Université de Genève dissertation. Jespersen, Otto. 1924. The philosophy of grammar. London: Allen \& Unwin.

Keenan, Edward L. 1985. Relative clauses. In Language typology and syntactic description, 141-170. Cambridge: Cambridge University Press.

Keenan, Edward L. \& Bernard Comrie. 1977. Noun phrase accessibility and Universal Grammar. Linguistic Inquiry 8(1). 63-99.

Kühner, Raphael \& Bernhard Gerth. 1963 [1904]. Ausführliche Grammatik der griechischen Sprache. 2. Teil: Satzlehre. München: Hueber.

Lehmann, Christian. 1984. Der Relativsatz: Typologie seiner Strukturen, Theorie seiner Funktionen, Kompendium seiner Grammatik. Tübingen: Gunter Narr.

Luraghi, Silvia. 2003. On the meaning of prepositions and cases: The expression of semantic roles in ancient Greek. Amsterdam: John Benjamins.

Malchukov, Andrej L. 2000. Dependency reversal in noun-attributive constructions: Towards a typology. München: Lincom.

Quirk, Randolph. 1957. Relative clauses in educated spoken English. English Studies 38(1). 97-109.

Rijksbaron, Albert. 1981. Relative clause formation in Ancient Greek. In A. Machtelt Bolkestein, Henk A. Combé, Simon C. Dik, Casper De Groot, Jadranka Gvozdanović, Albert Rijksbaron \& Co Vet (eds.), Predication and expression in Functional Grammar, 235-259. London: Academic Press.

Rijksbaron, Albert. 2002. The syntax and semantics of the verb in classical Greek: An introduction. Amsterdam: J.C. Gieben 3 rd edn.

Schwyzer, Eduard \& Albert Debrunner. 1953. Griechische Grammatik auf der Grundlage von Karl Brugmanns griechischer Grammatik. syntax und syntaktische Stilistik. München: Beck.

Smyth, Herbert Weir \& Gordon M. Messing. 1956. Greek grammar. Cambridge, MA: Harvard University Press. 